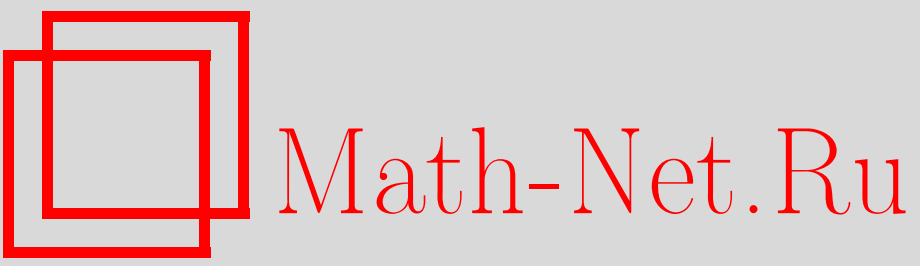

Олег Иванович Завьялов, TMФ, 2005, том 142, номер 1, 3

DOI: https://doi.org/10.4213/tmf2070

Использование Общероссийского математического портала Math-Net.Ru подразумевает, что вы прочитали и согласны с пользовательским соглашением

http://www.mathnet.ru/rus/agreement

Параметры загрузки:

IP: 54.89 .56 .158

26 апреля 2023 г., 16:38:14 
11 декабря 2004 года скончался заместитель главного редактора нашего журнала

\section{Олег Иванович Завьялов}

На протяжении многих лет Олег Иванович был одним из руководителей журнала. До конща жизни он принимал деятельное участие в работе редколлегии и вел активную научную работу. Его последняя статья опубликована в декабрьском номере журнала ТМФ за 2004 год.

Редколлегия выражает глубокие и искренние соболезнования родным и близким Олега Ивановича. 